\title{
Mind the Gap: Management System Standards Addressing the Gap for Ontario's Municipal Drinking Water, Wastewater and Stormwater Ecosystem of Regulations
}

\author{
Edgar Tovilla ${ }^{1,2}$ \\ 1 Environmental Applied Science and Management, University of Ryerson, Toronto, ON L4E 0J6, Canada; \\ etovilla@ryerson.ca; Tel.: +1905-237-2415 \\ 2 Environmental Services, Town of Georgina, Keswick, ON L4P 3G1, Canada
}

Received: 3 August 2020; Accepted: 26 August 2020; Published: 31 August 2020

check for updates

\begin{abstract}
The research finds evidence in support of and wide recognition of the practical value of management system standards (MSS) by assisting municipalities in meeting their human health protection, environmental objectives, addressing environmental and property damage risks, and providing an additional mechanism of public accountability and transparency. Semi-structured interviews were applied to assess perceptions with practitioners and environmental non-governmental organizations on whether a similar approach to the legally required drinking water quality management standard (DWQMS) could be applied for the municipal wastewater and stormwater sectors. Twelve Ontario municipalities have adopted or are in the process of adopting an ISO 14001 environmental management system (EMS) standard for their wastewater and/or stormwater systems, which represents $66 \%$ of Ontario's population. With the large urban centres (e.g., Toronto, York Region, Durham Region, Halton Region and Peel Region) adopting the standard, this is likely to influence small to medium-sized cities to follow a similar approach. Although, resources might be a factor preventing the cohort of smaller utilities voluntarily taking this path. Regulations governing Ontario's municipal drinking water, wastewater and stormwater utilities were compared via gap analysis. Gaps on management of the system, performance monitoring, auditing and having minimum design criteria left the municipal wastewater and stormwater sectors behind in comparison with recently updated (2004-2008) regulatory framework for the drinking water sector. Based on the identification and review of significant gaps in wastewater and stormwater regulation (compared with the drinking water sector), environmental MSS should be incorporated to strengthen the regulatory framework of these sectors. These phenomena also depict a form of sustainable governance with the use of MSS, which are initiated, developed and regulated by non-state actors, recognizing the value of non-state rule instruments in the water, wastewater and stormwater sectors.
\end{abstract}

Keywords: DWQMS; environmental management systems; ISO 14001; wastewater management; stormwater management; sustainable governance

\section{Introduction}

In a broader context, the objective of municipal water systems (i.e., drinking water, wastewater and stormwater) is to remove potential contaminants in the water taken from surface and underground sources for human uses, and then to clean it after it has been used and polluted before its discharge to the environment. Then, the cycle repeats again for downstream communities. It is within this context that the integrated and effective management is needed to coordinate such efforts and ensure that resources are there to achieve these objectives. However, every once in a while, there are triggers 
and incentives that prompt the government apparatus to modernize and improve on its obligation to protect human health and the environment.

Prior to the Walkerton tragedy (2000), when an estimated 2,300 people became seriously ill and seven people died from exposure to microbially contaminated drinking water in Walkerton, Ontario, a town of approximately 5,000 people located northwest of Toronto [1] (pp. 98-101), all water sectors were governed under the same regulatory framework. This framework included the Ontario Water Resources Act (first enacted in 1956) and the Environmental Protection Act (first enacted in 1990). Following several lawsuits [2] (pp. 522-529), and an independent public inquiry, known as the Justice O'Connor's Inquiry [3,4], the government of Ontario modernized its legislation on municipal drinking water [5] (p. 215). In Tovilla and Webb [6], the new regulatory framework is summarized, consisting primarily of three statutes, 11 regulations and related guidelines. All were developed in a span of seven years following the Walkerton Inquiry (2002). The resultant new governance framework for Ontario's drinking water follows a risk-based management approach and includes a legislatively mandated quality management system (QMS) developed for drinking water (the Drinking Water Quality Management Standard, or DWQMS). This is what is referred to in this paper as the ecosystem of regulations, a network of rule instruments intertwined with requirements to address the same policy objective (i.e., Justice O'Connor's Inquiry recommendations). The DWQMS, established in 2007, draws on the non-state standards, such as ISO 9001 for QMS, as well as the Hazard Analysis and Critical Control Points (HACCP) for the food industry, and also considered elements of ISO 14001 standard for Environmental Management Systems (EMS) $[3,4,7]$. Non-state standards are standards developed by non-state entities in response to public concerns, human tragedy, and environmental crises or as precautionary measures [8] (p. 43). While government rule instruments provide minimum standards, non-state standards are developed and updated more frequently and may be more stringent than government criteria [9] (p. 75).

There is a growing governmental recognition in federal-provincial-municipal legal frameworks of the value of drawing on non-state EMS standards as part of environmental protection efforts [6]. This is evidenced in the Canadian court decisions or court hearings to impose EMS standards based on ISO 14001 on water utilities (see municipalities in red on Figure 1). It is also evidenced in the voluntary actions of some municipalities to adopt EMS standards in their wastewater operations (see municipalities in black font on Figure 1). Figure 1 indicates the 2017 municipal estimated population (in millions) against the year the utility adopted the EMS standard for their water and/or wastewater system, including a projection based on the interview responses part of this study.

The term EMS, first introduced in the global sustainable development agenda in the 1970s-United Nations 1972 Conference on the Human Environment in Stockholm-[10] (pp. 226-227), is used in this study as a standard designed to assist organizations in addressing their environmental impacts and obligations to support environmental protection and prevention of pollution in balance with socioeconomic needs [11].

In this paper, the term "value" means the practical utility of municipalities applying EMS standards to assist in achieving environmental objectives and societal expectations. Practical utility is here considered to include such features as: possible assistance in meeting legal requirements and thereby decreasing the likelihood of regulatory violations taking place, assistance in demonstrating due diligence when violations occur, increasing consistency in operations and assistance in demonstrating accountability, transparency and good governance to the public and stakeholders.

In other jurisdictions, there has also been increasing use of international EMSs for municipal wastewater systems. In 2005, the United States Environmental Protection Agency (US EPA) created the Guide for Evaluating Capacity, Management, Operation, and Maintenance (CMOM) Programs at Sanitary Sewer Collection Systems, a guide that includes many of the elements of the ISO 14001 [12]. This is a voluntary program, although it is also referred to in abatement orders to some municipalities [13]. As an example, in response to drinking-water-related tragedies that occurred in Milwaukee, Wisconsin 
(1993), and Flint, Michigan (2014), both states now established voluntary programs referencing ISO 14001 for their wastewater systems [14-18].

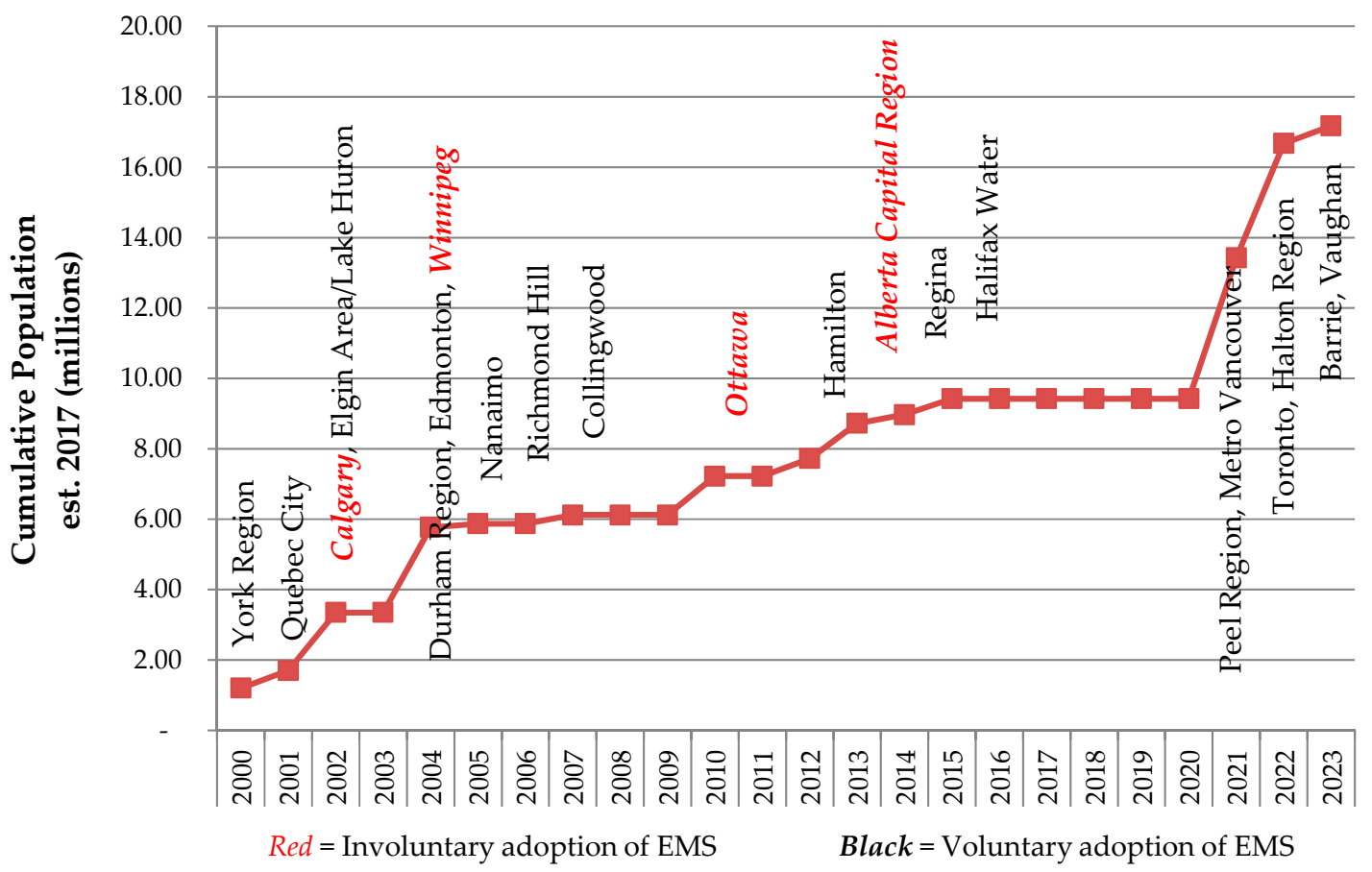

Figure 1. Growth of EMS for water and wastewater systems in Canada. Note: After the DWQMS was published in 2007, adoption of EMS went stagnant. This is explained as all Ontario municipalities were busy implementing the DWQMS on drinking water (legally mandated in 2008-2009). Two triggers resulted in having incentives for municipalities to resume their attention to EMS for wastewater: First, the environmental violations in Ottawa (2008-2011) in a case publicly known as the 'sewergate', which resulted in public opinion making the city adopt elements of ISO 14001. Second, a 2014 environmental violation case, which resulted in a federal court decision to have the Alberta Capital Region implement an EMS based on ISO 14001.

The use of EMS standards initiated, developed and regulated by non-state actors is also consistent with certain conceptions of governance that recognize the value of using the non-state rule instruments, and it aligns especially well with the concept of sustainable governance [19] (pp. 278-279). The sustainable governance approach is based on the premise that a combination of state and non-state rule instruments, institutions, processes and actors are particularly well positioned to address complex and evolving environmental issues and other issues of public interest-involving collaboration between state and non-state actors in some cases and more of a check-and-balance dynamic in others.

While generally, standards or voluntary codes are developed by non-state actors to "bridge the gap" [20] (p. 810) and address limitations in state-based command-and-control rule instruments, there is literature critically assessing and questioning the salutary and beneficial aspects of voluntary management system standards (MSS) initiatives. Kollman and Prakash [8] (p. 43), Chatterji and Toffel [21] (p. 917) and Simpson and Sroufe [22] (p. 830) argued that reporting and validation are deflectors of attention rather than performance and process improvements. The risk posed by a stagnant EMS, whether state-based or non-state, is that it may reduce the incentive for innovation, and some authors suggest that there is a risk that MSSs may inadvertently discourage diversity of environmental management practices by encouraging "going by the book" compliant behaviour [21] (pp. 918, 919); [22] (pp. 845-846). Nonetheless, Arimura et al. [23] (p. 293) argued that this also applies to command and control regulations. These critical arguments are outweighed by arguments in support of MSSs which underscore its benefits, including positive impacts on performance (for 
EMS), opportunities for innovation, enhanced cost efficiency, improved stakeholder relations, external legitimacy and positive influence on stakeholders [24] (p. 56); [25] (p. 162); [26] (p. 303); [27] (p. 125). At a time when social media is so prevalent for any organization providing a service to the public, having an improved standardized approach for reporting and validating is more of a necessity.

A review of the literature on management system standards (MSSs) provides insights into their original uses, strengths and weaknesses, leading to an exponential development of new sector-specific standards for various sectors. As applied in this study, MSSs are normative documents that articulate acceptable vs. unacceptable behaviour. Scholars point to an increasing uptake of specific non-state standards by state environmental regulations, noting that while state rule instruments provide minimum standards, non-state standards are developed and updated more frequently and may be more stringent than government criteria [9] (p. 10); [28] (p. 75); [29] (p. 278). Figure 2 illustrates a synopsis of triggers and incentives for state-based and non-state-based rule instruments and standards in general. This diagram reveals that both types of standards (rule instruments) are developed in response to public concerns, human tragedy, an environmental crisis or as precautionary measures [8] (p. 10); [28] (p. 75). This explanation of the factors that trigger standards intersects with the sources leading to policy innovation (e.g., new policy goals, uncertainty, stricter policies, new scientific insight, disasters, disease, tragedies and catastrophic events).

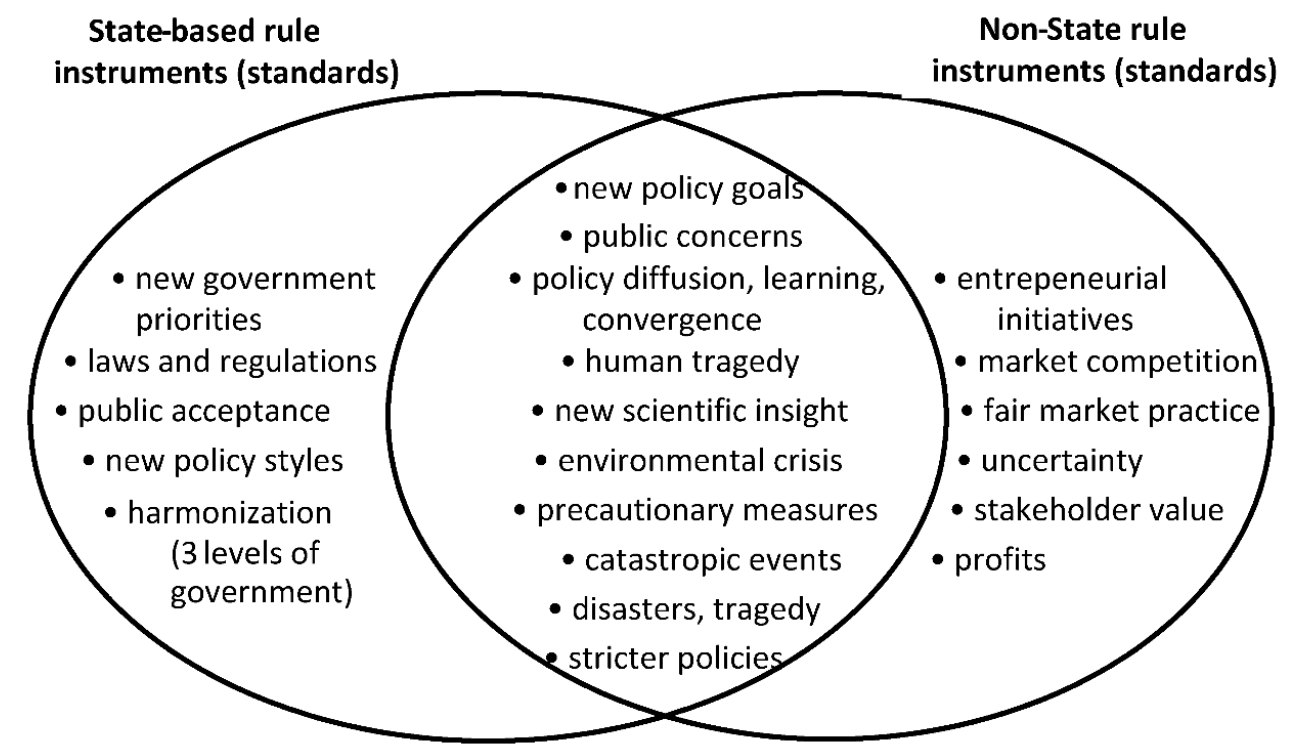

Figure 2. Triggers and Incentives for State and Non-state Rule Instruments and Standards.

Historically, a major incentive for developing MSSs was to address interorganizational and interjurisdictional harmonization and reduce inefficiencies [30] (p. 47); [31] (pp. 523-541). Although primarily used by profit-driven organizations, there is increasing evidence of MSSs being used by all three levels of government to supplement government regulation [10] (pp. 38-42).

The International Standards Organization (ISO) is an independent, global, nongovernmental organization made up of members from the national standards bodies of 162 countries and is the world's largest developer of voluntary international standards (the CSA Group is the largest national standard body in Canada). By definition, all ISO standards are voluntary in the sense that ISO is a non-state body and therefore is incapable of requiring an organization to comply with its standards the way governments can require and enforce adherence to laws. Both the ISO 9001 for quality management and the ISO 14001 for environmental management are standards relevant to this study as they were used (as well as the Hazard Analysis and Critical Control Points for the food industry) for the development of the DWQMS $[3,4,7]$. 
In Ontario, after 10 years of experience with the provincially required DWQMS, municipalities have generated a body of knowledge about the value of MSSs, and this knowledge is now proactively being expanded from its use in drinking water management to wastewater and stormwater [6] (p. 225); [32]. This study suggests that there is a slow but steady transfer of knowledge concerning MSS approaches from the municipal drinking water to the wastewater and stormwater sectors. In part, the transfer involves a community of officials in municipal water utilities that are growing more knowledgeable about, benefiting from and drawing on MSSs to address environmental performance in their operations.

This study argues that ISO QMS and EMS standards appear to be forming a conceptual "bridge" between state and non-state actors [20] (p. 810). Such bridge appears to be creating a sustainable form of governance with an increasing reference to such standards in legislation and related government documents and in court decisions. The sustainable governance with respect to the value and use of QMS standards for drinking water activities and EMS standards for wastewater and stormwater activities [6] (p. 224).

Figure 3 offers a depiction of a sustainable governance perspective on the array of state and non-state actors (and associated rule instruments, institutions, processes and actors) variously involved in municipal water governance. For the purposes of Figure 3, municipalities are positioned at the centre of a sustainable governance-type system with evolving roles for state and non-state actors, all of which provide some form of regulatory and non-regulatory stimuli for improved water management and environmental protection, leading toward a state/non-state convergence of governance approaches applying to municipal water management.

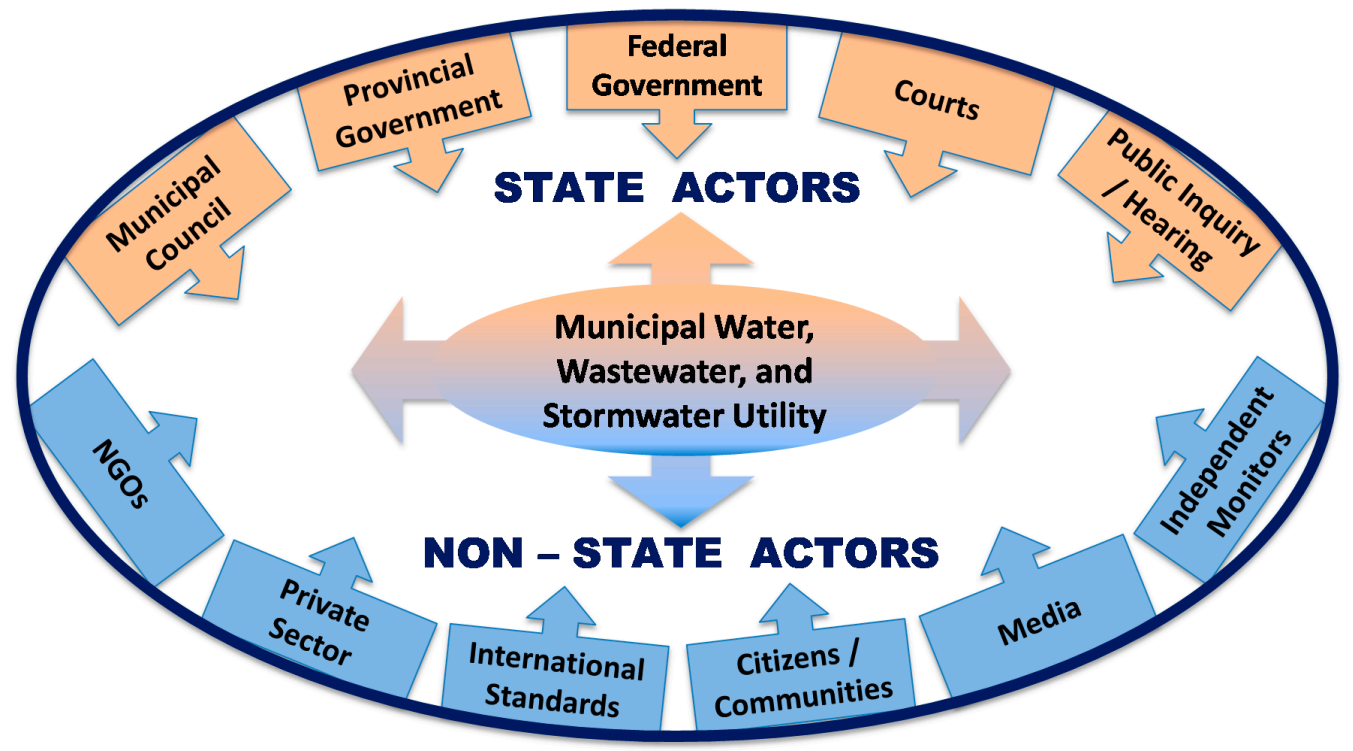

Figure 3. Depiction of a sustainable governance approach-Municipal water sectors.

Municipalities are uniquely placed to highlight particular regulatory gaps and limitations that have been revealed in the implementation of the regulatory framework put in place following the Walkerton Inquiry [3,4]. An increasing reliance upon EMS can be seen as a partial response to some of the previously existing gaps and limitations in the regulatory approach. While the situation has improved with the introduction of a new regulatory regime and a quality management system standard for the protection of drinking water, the wastewater and stormwater regulatory regimes have been left largely untouched and still rely largely on a regulatory framework put in place in the 1950s. The new regulatory regime for a drinking water system includes a minimum design criteria, critical control points (CCP) embedded in legislation, including a 3-stage disinfection requirement at the water treatment, storage and distribution systems, and a quality MSS. Preliminary research suggests that 
ISO-type environmental management system standards, as well as other regulatory tools, could be useful supplements for wastewater and stormwater regulation [6] (p. 224).

This study suggests that the adoption of MSSs for wastewater and stormwater aligned to ISO 14001 could be expected to generate value and positive benefits, including incentivizing ongoing performance improvements and technological innovation. The ecosystem of regulations including the DWQMS has shown that tracking, auditing and publicly reporting performance metrics such as CCPs incentivize public utilities to improve performance [33] (p. 2), and bring new smart systems technologies for monitoring, data analytics, process optimization and reporting [34] (p. 677); [35] (p. 11). In addition, the adoption of EMS standards and certification processes could create an extra layer of protection in the form of third party inspection and compliance activity beyond that conducted by governmental inspection and compliance activities.

The research outlined here reveals that some municipalities in Canada and elsewhere have already voluntarily secured ISO 14001 certification for their water/wastewater/stormwater operations. Arguably, one motivation for the adoption of EMS is recognition of the potential for the regulated entity to rely upon certification as a defense of due diligence in the event of prosecution, as a strategy to reduce regulatory liability (and if convicted, there could be grounds for the regulated entity to file a lawsuit for negligent certification). This can be seen as additional support for the proposition that there is convergence between state and non-state sectors in recognition of the value of adopting EMS and other non-state governance approaches as a way to stave off regulatory liability (i.e., to forestall, counter and defend against prosecutions under environmental protection laws and regulations) [6].

The terms wastewater and sewage in Canadian federal and provincial legal contexts refer to both sanitary wastewater and stormwater. This study uses the terms wastewater and stormwater as distinct concepts, as the two terms have different management requirements for their infrastructure and are subject to different inputs and outputs. Stormwater is subject to the uncertainties of weather conditions (i.e., rain intensity and duration), while wastewater has more defined sources and generally has separate drainage systems.

\section{Methods}

For this study, a non-experimental method was used, applying descriptive and qualitative research components in the form of semi-structured interviews. The literature review for this study was the subject of another paper published by the author and his PhD supervisor [6]. This paper makes reference to that literature review as appropriate. The interview method was undertaken with a view to addressing the following research sub-questions:

- Are management system standards likely to have neutral, positive or negative effects on the performance of Ontario municipal water management activity?

- Which MSS standards relevant to the water sectors (ISO 9001-QMS, ISO 14001-EMS and HACCP) are best suited to address municipal water, wastewater and stormwater activity?

A total of 25 interviews with respondents from government, the private sector and civil society were conducted for this study, using semi-structured, open-ended questions. The semi-structured, open-ended approach provided interviewees with the opportunity to elaborate on points of interest and thus increased the value of the data. Interviews were conducted from September 2016 through July 2019. The one-time individual interviews were conducted in a sequential approach creating a "concurrent triangulation" method [36] (p. 162) in tandem with other research methods (i.e., case studies and a focused group session), which are not included in this article. The initial interviews with regulators and experts in the field and input from the case study method contributed to enriching and adding additional questions, which sequentially led to additional interviews with new experts and into a focused group session as the final research method applied [32]. The interviews were conducted in compliance with Ryerson University's Review Ethics Board approval received in August 2016 [10] (pp. 255-256). 
The initial interview questions were developed by the author. The objective of the interviews was to collect information in order to better understand the governance context within which MSSs operate from a municipal, consultant and environmental non-governmental organizations (ENGOs) viewpoint. Additional questions were added as a result of the initial questions and also from the input of the case study method (the latter not subject to this article). The multimethod research approach allows for what Cresswell et al., referencing Hossler and Vesper, refer to as a "concurrent triangulation method design" [36] (p. 162). Carter et al. [37] (p. 545) noted that triangulation is a way to test validity through separate data analysis, and the integration of databases at the interpretation or discussion stage of the report. Consent forms and a letter of information about the study were provided two weeks in advance to all interviewees. Specific insights were sought concerning:

(a) enablers and barriers for the adoption of management system standards;

(b) perceptions in relation to selecting a QMS and EMS;

(c) perceptions in relation to the positive, neutral or negative effects of an EMS;

(d) governance interactions;

(e) the value of creating a provincially required EMS for municipal wastewater and stormwater systems; and

(f) rival propositions for the use of MSSs (e.g., going by the book, inhibiting innovation, etc.).

Although the interview questions focused on water MSSs and governance approaches, they were also designed to provide opportunities for comment by interview respondents on related issues, such as policy convergence and future regulatory paths. Potential respondents were identified via organizational websites, publications in journals and articles from magazines associated with organizations, such as the Water Environment Association of Ontario (WEAO), the Ontario Municipal Water Wastewater Regulatory Committee (MWWRC), and the Ontario Water Works Association.

All municipalities that have an ISO 9001 and/or ISO 14001 certification were targeted for interviews (Table 1). The directory of the MWWRC provided access to the contact information of more than 150 municipal officials in Ontario. An attempt was made to interview federal regulators from Environment and Climate Change Canada, but they responded that municipal water management is a provincial responsibility and no interviews were secured. Requests were also made for interviews of provincial regulators, but they were not accepted on the basis that the provincial regulatory body (Ministry of the Environment, Conservation and Parks, also referred to as MECP) has no regulatory requirements for MSSs for municipal wastewater and stormwater systems, however, they did participate in the focus group method.

Potential respondents were initially contacted by the author, who attempted to ensure that a broad range of perspectives were elicited from municipal officials from small and large municipalities, consultants, ENGOs and non-state regulators (e.g., standards bodies). From a total of 32 professionals contacted, 25 respondents accepted the invitation. This represented a rate of response of $78 \%$.

Table 1 shows a total of twelve (12) Ontario municipal utilities that have adopted or are in the process of adopting an EMS for their water, wastewater and stormwater systems. This table also shows five (5) utilities that have the ISO 14001 certification; two (2) that have a self-declaration of an EMS for their wastewater system; and five (5) utilities that are in the process of adopting an EMS for their wastewater systems. The Elgin Area Water and the Lake Huron Water are managed by one utility and therefore counted as one single utility.

The interviews were conducted by the author using a face-to-face approach. A distribution of participants by sector is presented in Figure 4. All participants were involved in drinking water, wastewater and stormwater systems, and with some form of environmental governance in Ontario.

Most interviews were conducted between 2016 and 2018. The interviews with the four representatives of ENGOs were conducted in 2018. The analysis consolidates all 25 interviews. Figure 5 shows interview respondent roles within their organizations. 
Table 1. Municipalities with ISO 9001, ISO 14001 or HACCP.

\begin{tabular}{cccccc}
\hline \multirow{4}{*}{ Municipality } & ISO 9001 & ISO 14001 & HACCP & ISO Certification \\
\hline \multirow{5}{*}{ ISO Certified } & York Region & $\checkmark$ & $\checkmark$ & - & Since 2000 * \\
\cline { 2 - 6 } & Elgin Area Water & - & $\checkmark$ & - & Since 2002 \\
\cline { 2 - 6 } & Lake Huron Water & - & $\checkmark$ & - & Since 2003 \\
\cline { 2 - 6 } & Richmond Hill & $\checkmark$ & $\checkmark$ & - & Since 2006 \\
\cline { 2 - 6 } & Durham Region & $\checkmark$ & $\checkmark$ & $\checkmark$ & Since 2006 \\
\cline { 2 - 6 } Under & Collingwood & - & $\checkmark$ & - & From 2007 to 2015 \\
\cline { 2 - 6 } Development & Region of Peel & $\checkmark$ & $\checkmark$ & - & Estimated for 2021 \\
\cline { 2 - 6 } & City of Toronto & - & $\checkmark$ & - & Estimated for 2022 \\
\cline { 2 - 6 } & Halton Region & $\checkmark$ & $\checkmark$ & - & Estimated for 2022 \\
\cline { 2 - 6 } & City of Vaughan & - & $\checkmark$ & - & Estimated for 2023 \\
\cline { 2 - 6 } Self-Declaration & City of Barrie & - & $\checkmark$ & - & Estimated for 2023 \\
\cline { 2 - 6 } & City of Ottawa & - & $\checkmark$ & - & Since 2010 \\
\cline { 2 - 6 } & City of Hamilton & - & $\checkmark$ & - & Since 2012 \\
\hline
\end{tabular}

$\left(^{*}\right)$ Adopted ISO 14001 for wastewater only in 2000 and ISO 9001 for drinking water in 2001.

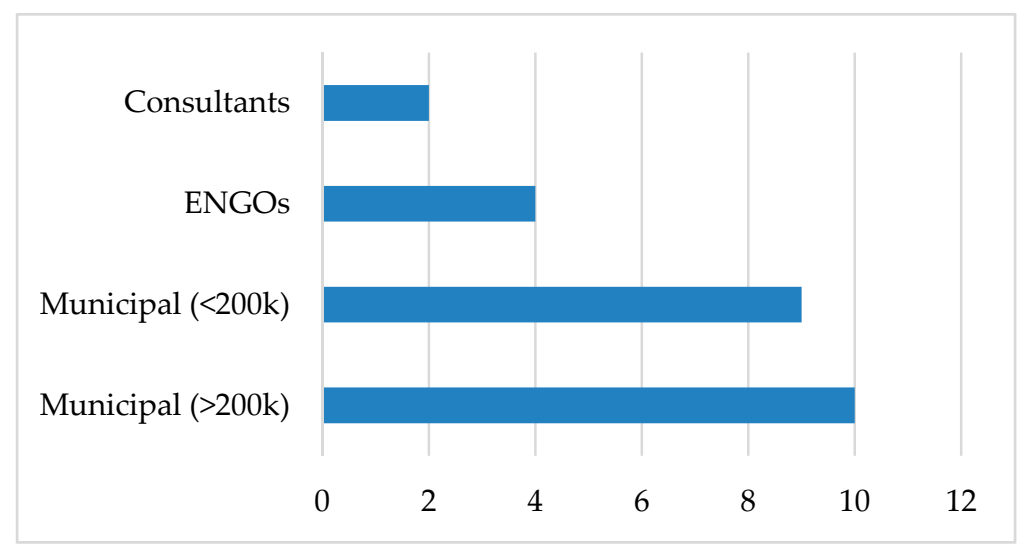

Figure 4. Interview respondent distribution.

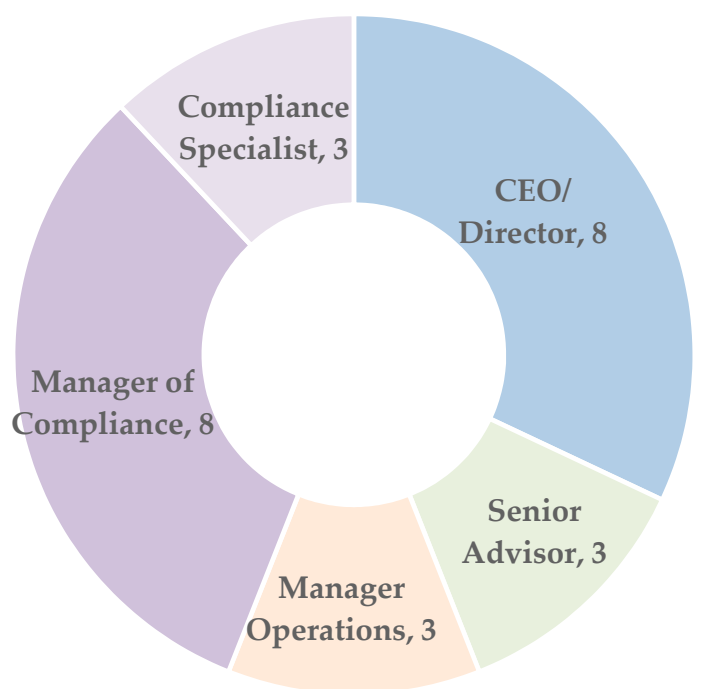

Figure 5. Interview respondent roles. 


\section{Results}

The results are presented in three sections. First, five key questions and the responses to them were reviewed quantitatively to analyze the respondents' perceptions concerning MSSs for municipal water systems. This is followed by a classification of qualitative data in terms of enablers and barriers, governance and procedural aspects in relation to MSSs. Finally, the qualitative data were examined with a focus on the relevant position taken by the respondents, and particularly on the following:

(a) relevance to municipalities of voluntarily adopting non-state regulatory standards, such as ISO 14001 or ISO 9001;

(b) regulatory barriers to modernizing the Ontario municipal wastewater and stormwater regulatory framework; and

(c) provincial regulatory priorities associated with improving the protection of freshwater quality from potential contamination from municipal wastewater and stormwater.

The interviews took place before and after the province was conducting a public consultation (2016-2017) regarding proposed updates to the DWQMS. This meant that most respondents were familiar with the DWQMS and proposed amendments to its original 2007 version.

\subsection{Key Interview Questions}

Five key questions were included for the interviews:

1. Do you consider an MSS to have neutral, positive or negative effects for the Ontario water sectors?

2. Should Ontario municipalities have a voluntary or mandatory wastewater and/or stormwater management system standard based on ISO 14001 ?

3. In terms of MSSs, are ISO 14001 and/or ISO 9001 the best fit for drinking water, wastewater and stormwater systems, or is there something better that should be used?

4. Does an MSS that is not regularly revised and updated pose an organizational risk because it does not encourage ongoing innovation and instead rewards "going by the book" behaviour?

5. Do you have any ideas as to why only a subset of Ontario municipalities have voluntarily adopted ISO 14001 as of $2016 ?$

For Question No. 1: a total of $88 \%$ of respondents (22/25) answered that implementing an MSS would have positive effects for the municipal water sectors.

For Question No. 2, the responses can be grouped as follows:

- $\quad 77 \%$ considered that EMS should be a regulatory requirement;

- $15 \%$ considered that EMS should be either a voluntary or regulatory requirement;

- $10 \%$ considered that EMS should be a voluntary requirement.

For Question No. 3, the response breakdown is as follows:

- $100 \%$ considered ISO 9001-QMS the best fit for drinking water systems;

- $\quad 95 \%$ considered ISO 9001 redundant for drinking water systems as DWQMS addresses water quality controls;

- $\quad 95 \%$ considered ISO 14001-EMS the best fit for wastewater and stormwater systems;

- $60 \%$ considered that ISO 14001-EMS could address the environmental protection regulatory gaps for drinking water systems.

One respondent to this question highlighted the possibility of mirroring the DWQMS for the wastewater and stormwater sectors; however, the remaining 19 respondents concurred on the need for a sector-specific EMS for wastewater and for stormwater and recommended integration with the ISO family of MSSs in order to avoid duplication. Three respondents noted that their municipality has 
also adopted ISO for health and safety, and the recent 2015 version of ISO standards makes them easy to integrate.

For Question No. 4, a total of 5 respondents answered affirmatively, and 20 did not. Three quarters of respondents noted the importance of MSS in promoting innovation throughout the organization. This was characterized as occurring through the ISO 14001 continual improvement process and its associated root cause analysis (RCA). RCA is a procedural participative process applying investigative techniques to resolve problems/issues at the root cause, so as to prevent similar issues from happening again. Techniques noted by one of the respondents include the fishbone diagram (i.e., a cause-and-effect diagram also known as the Ishikawa diagram [38], the 5-Ws process (i.e., asking 'why' five times or until reaching the root cause of an issue) (Strong $\mathrm{n} / \mathrm{d}$ ), and the failure mode analysis (i.e., a methodology to minimize risk with reliability and statistical analysis [39]. While RCA is not a requirement under ISO 9001 or ISO 14001, some type of investigation mechanism is. Strong noted that most registrars and ISO consultants include these RCAs as techniques to implement the ISO requirement for a continual improvement process [40].

With respect to Question No. 5, all respondents noted that the primary driver for adoption of the standard was the desire to anticipate upcoming provincial regulations as recommended in the Walkerton Inquiry [3,4] and also the support it received from upper management and city councilors in light of the tragedy. Moreover, after the DWQMS guide was published and the implementation calendar was legislated under the Ontario Regulation 188 in 2007 (O. Reg. 188/07), all municipalities concentrated their efforts on developing, implementing and complying with the DWQMS.

An attempt was made to organize the information collected into the categories of enablers and barriers, and in governance and procedural aspects. This approach applied Yin [41] (p. 32) codification as a means to enhance the ability to identify key differences and similarities concerning programs/policies and program implementation.

\subsection{Enablers, Barriers, Governance and Procedural Aspects}

Respondents' answers are classified under enablers or barriers, and each concept is identified in terms of governance aspects, and also in terms of procedural aspects. The data are presented in separate graphs: two for MSS enablers, governance aspects (Figure 6), and procedural aspects (Figure 7).

The most common topic in support of the use of MSSs is compliance, and the reduced likelihood of environmental violations, followed by the ability to enhance the municipalities' due diligence defence in the event of violations (Figure 6). Complementarity with existing state regulations, risk management and management accountability were also prominent as points in support for adopting MSSs.

As for implementation of these kinds of systems, Figure 7 reflects positions in support of MSSs including the ability to address regulatory gaps in state legislation by adding checks and balances to reduce risks. This aspect is significant as some respondents noted that provincial inspections of wastewater systems were infrequent (and basically non-existent for stormwater systems).

When discussing the rival propositions for the use of MSS, most respondents identified similar regulatory gaps in current legislation as the primary barriers to MSS implementation. Other MSS barriers included: uncertainty of regulations, development and implementation costs, and ongoing cost implications. The following figures illustrate the distribution of the most frequently cited topics in responses about MSS barriers. The data for MSS barriers, governance aspects is presented in Figure 8, and the procedural aspects in Figure 9. 


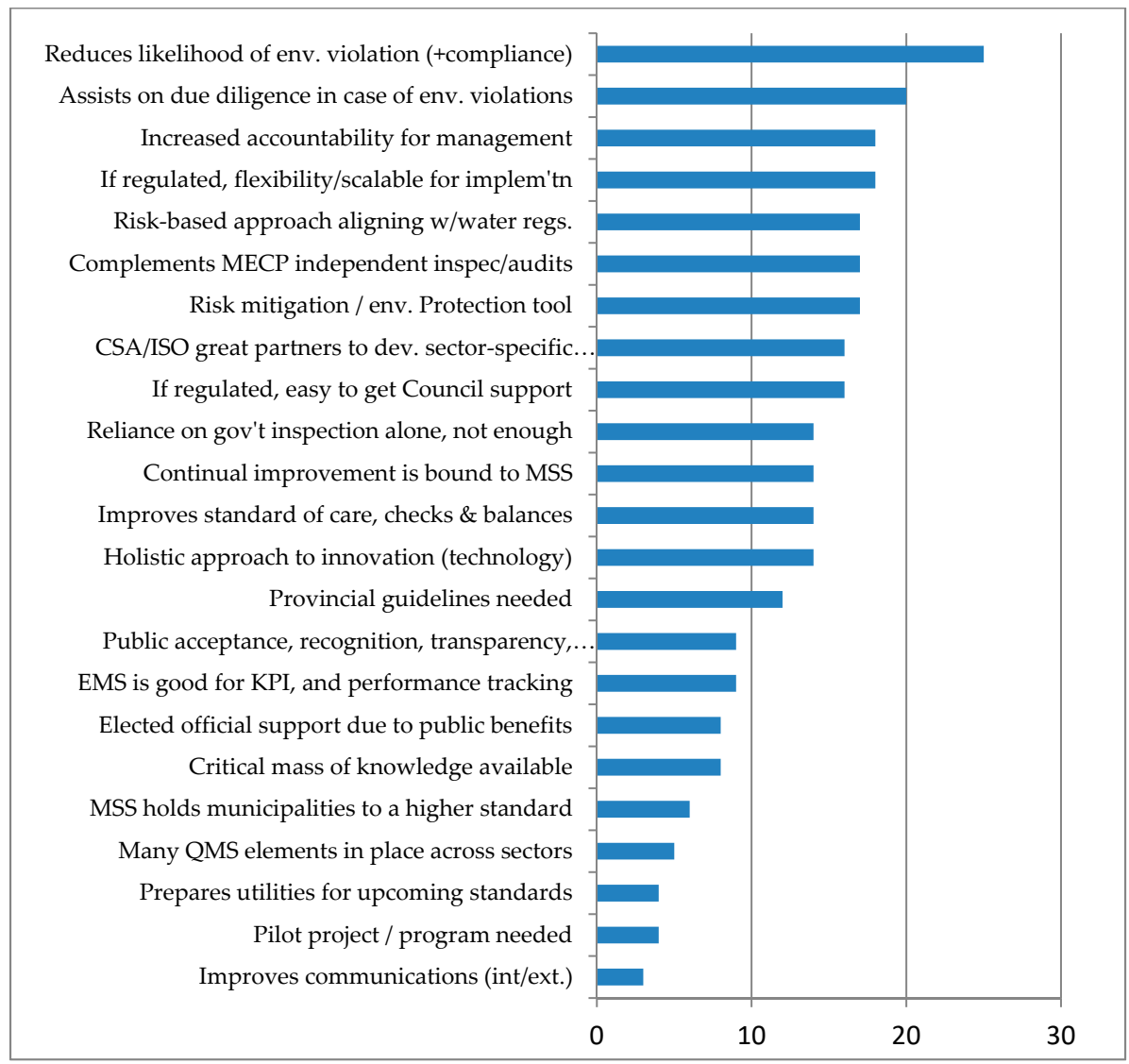

Figure 6. MSS Enablers-Governance aspects.

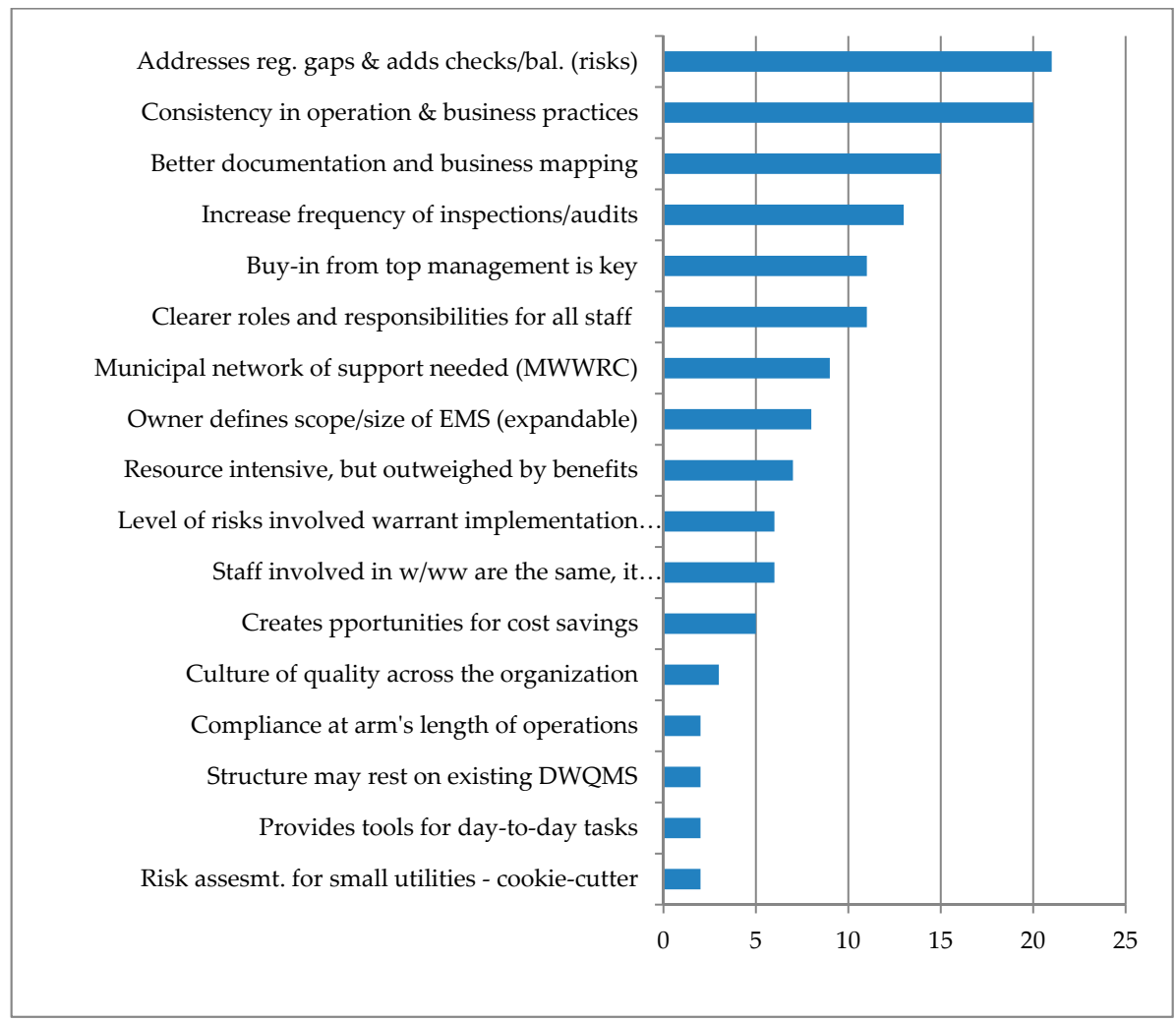

Figure 7. MSS Enablers-Procedural aspects. 


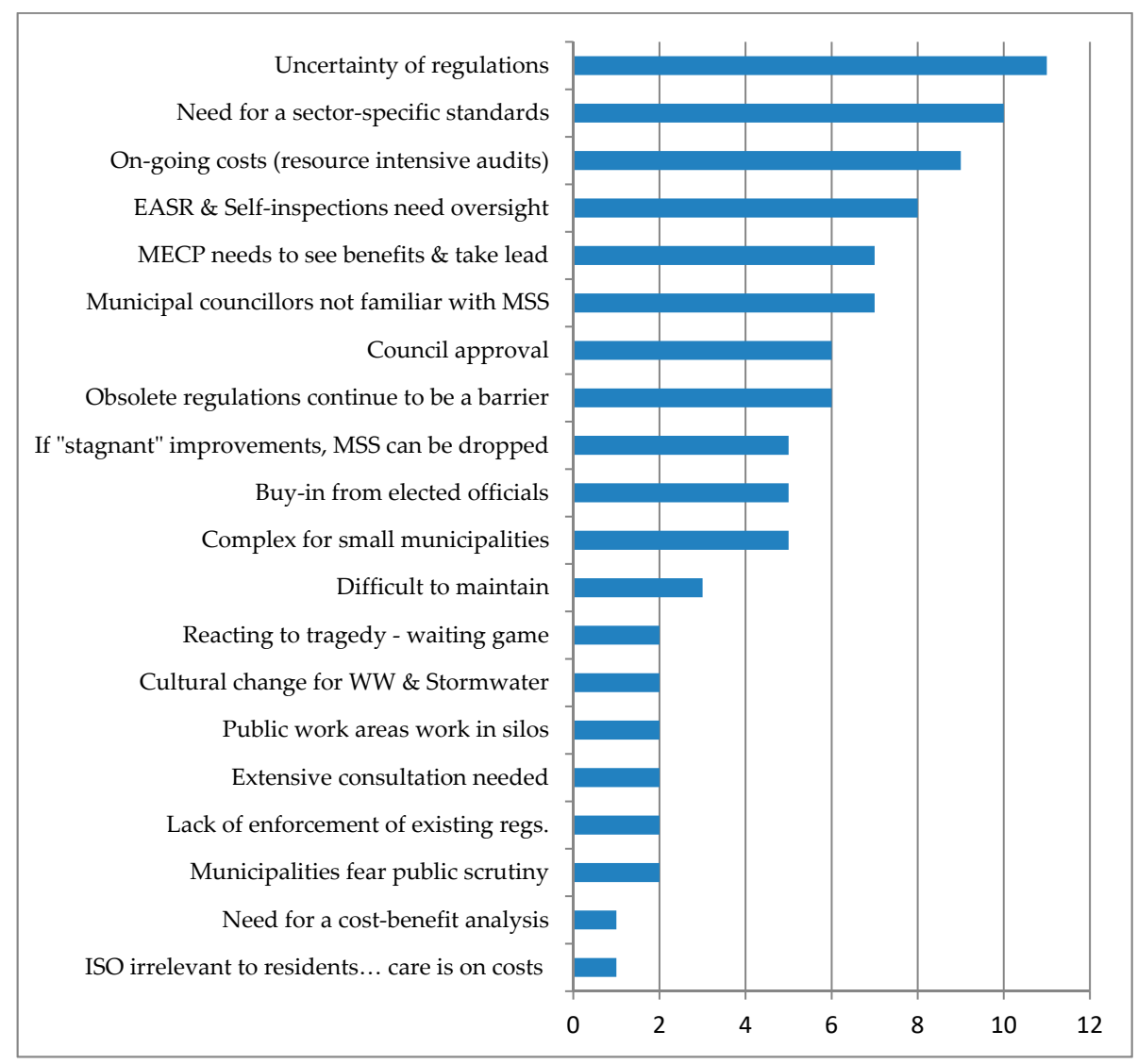

Figure 8. MSS Barriers-Governance aspects.

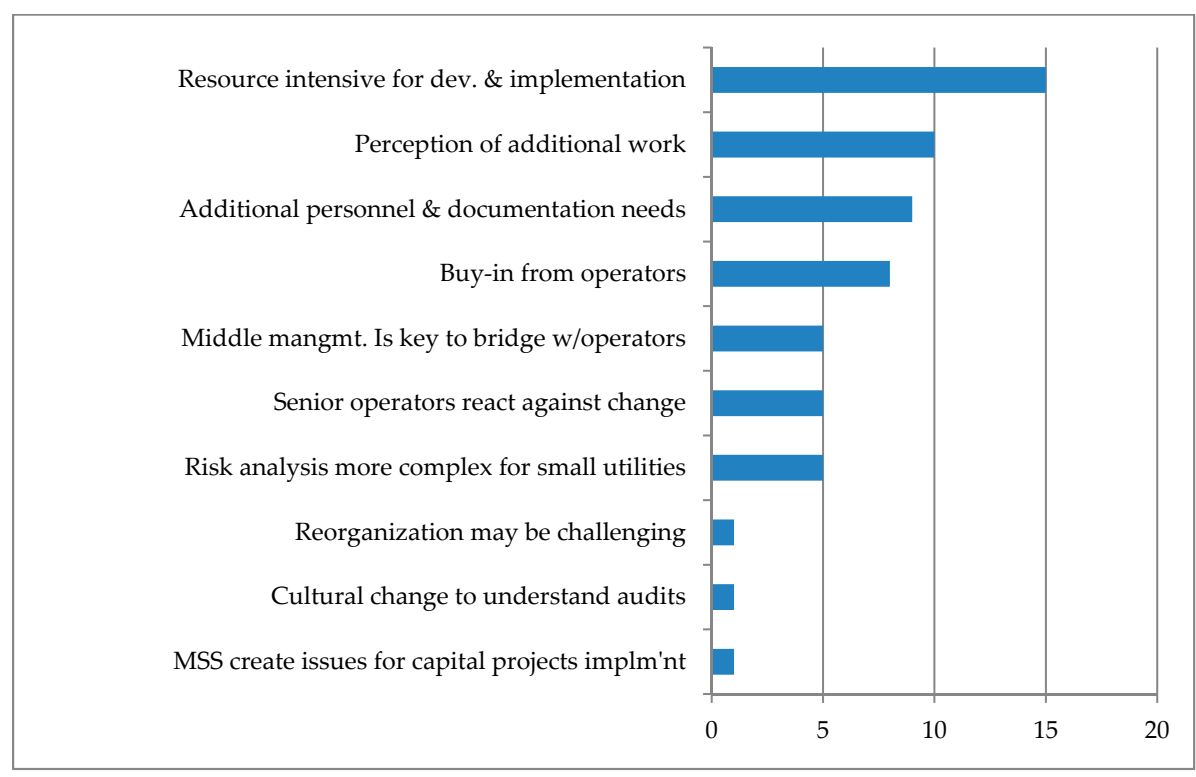

Figure 9. MSS Barriers-Procedural aspects.

The recurring responses included the uncertainty of regulations for the wastewater and stormwater (given that it heavily relies on guidelines, voluntary codes and best municipal practices). It was also noted that any MSS requires a significant amount of resources (i.e., defining the scope of the MSS, cost of ISO certification, external audits, additional staff to develop and ongoing staff to maintain the MSS, and cost for documenting/updating operating procedures) for implementation, and the expressed 
need for a sector-specific standard tailored to the wastewater and the stormwater sectors (similar to that of the DWQMS for the drinking water sector).

\subsection{Relevant Positions by Sector: Municipal, Consultants and ENGOs}

A total of 19 municipal representatives participated in the interview process. The data collected were coded and examined concerning the following topics:

A. relevance for municipalities of voluntarily adopting non-state regulatory standards, such as ISO 14001 or ISO 9001;

B. regulatory barriers to modernizing the Ontario municipal wastewater and stormwater regulatory framework; and

C. provincial regulatory priorities associated with improving the protection of freshwater quality from potential contamination from municipal wastewater and stormwater.

Table 2 summarizes the opinions and perceptions of all municipal representatives organized in topics $\mathrm{A}, \mathrm{B}$ and $\mathrm{C}$.

Table 2. Municipalities' specific viewpoints.

\begin{tabular}{|c|c|}
\hline Q & Municipal Interview Responses Classified under Topics A, B and C \\
\hline $\begin{array}{l}\text { Voluntary Adoption } \\
\text { Non-State MSS }\end{array}$ & $\begin{array}{l}\text { - "for managers [MSSs] are a great tool to ensure due diligence, and for staff it } \\
\text { provides the day-to-day tools [SOPs, documentation] for completing tasks, } \\
\text { and for training" M1 } \\
\text { "[MSS] is of great value as it provides a professional approach [to } \\
\text { operations]" M1 } \\
\text { "the EMS fills gaps in the legislation, such as water conservation, discharges } \\
\text { to the environment, audits" M2 } \\
\text { "operations are focused on operations. A holistic approach is needed, a big } \\
\text { picture" M4 } \\
\text { "for small municipalities [the DWQMS] was challenging. It became easier, } \\
\text { once municipalities networked through the MWWRC" M5 } \\
\text { "municipalities are already adopting DWQMS principles for wastewater } \\
\text { systems, because they are familiar with them and see the benefits" M14 }\end{array}$ \\
\hline Regulatory Barriers & $\begin{array}{l}\text { - "[the EMS] implementation is challenging. It is better to go in stages, by } \\
\text { - "fepartment or by facility" M2 } \\
\text { - "for small municipalities [an EMS] would be feasible if it is kept simple" M3 } \\
\text { "how to do corrective actions was weak in the first DWQMS, now it is better } \\
\text { understood" M10 } \\
\text { "having the buy-in [for a voluntary EMS] from both top management and } \\
\text { from front-line staff is paramount" M12 } \\
\text { "A cost-benefit analysis would assist municipalities before they embark on } \\
\text { such an undertaking [ ... ] it is better to wait and see what the province } \\
\text { decides to do" M13 }\end{array}$ \\
\hline $\begin{array}{l}\text { Prov. Regulatory } \\
\text { Priorities }\end{array}$ & $\begin{array}{l}\text { - "the MECP should develop a wastewater EMS, the ISO } 14001 \text { is a better } \\
\text { approach" M5 } \\
\text { "If an EMS is mandatory, it would be easier for municipalities to obtain } \\
\text { - } \quad \text { "there should not be designated registrars; this would make it easier and more } \\
\text { affordable to obtain ISO } 14001 \text { certification" M14 } \\
\text { - "it is a matter of time for the province to require an EMS for wastewater" M15 } \\
\text { - "if [an EMS is] left voluntary, then it will not fare well over time. [An EMS] } \\
\text { needs a stick. [Having a system registered under ISO 14001] is required" M16 }\end{array}$ \\
\hline
\end{tabular}


Municipal respondents had a significant number of positive and negative responses concerning the use of an MSS for wastewater and stormwater systems. There was generally recognition of the value and benefits, as well as the procedural aspects for implementation (e.g., MWWRC networking), including the critical mass of knowledge, as has happened with the DWQMS. Based on the responses provided, it was apparent that respondents had a good familiarity with ISO 14001 and the differences between it and the DWQMS. As noted earlier, these interviews occurred at the time the MECP had released a Draft DWQMS (2015) for public comment. This is an indicator of the awareness needed not only to improve the standard, but also of the acceptance by municipalities of the beneficial use of the standard.

Two consultants who participated in the interview process were specialists in MSS. Representative arguments on topics A, B and C. are included in Table 3.

Table 3. Consultants' specific viewpoints.

\begin{tabular}{|c|c|}
\hline $\mathbf{Q}$ & Consultants' Interview Responses Classified under Topics A, B and C \\
\hline $\begin{array}{l}\text { Voluntary Adoption } \\
\text { Non-State MSS }\end{array}$ & $\begin{array}{l}\text { - "the DWQMS was strategically designed for drinking water, and very limited } \\
\text { to address environmental issues [ ... ] [ISO } 14001 \text { is necessary] to effectively } \\
\text { manage impacts to the environment" C1. } \\
\text { "ISO } 14001 \text { is a big deal, and [a] great response to environmental groups and } \\
\text { public pressure" C1 } \\
\text { "[large] municipalities are already cloning their management systems, [i.e., } \\
\text { transferring their drinking water management systems approach to } \\
\text { wastewater] [ ... ] the body of knowledge created by the DWQMS is paying } \\
\text { dividends" C2 } \\
\text { "the operators had no identity [ ... ] [and then] after Walkerton, they were the } \\
\text { focus. Now, they are licensed, are responsible [ ... ] the MECP } \\
\text { professionalized the operation" C2 } \\
\text { "EMS will never be the fine screen to catch everything, but will likely catch the } \\
\text { big stuff. Like anchors in the system" C2 }\end{array}$ \\
\hline Reg. Barriers & $\begin{array}{l}\text { - "top management's on-going commitment is an issue [ ... ] there is always the } \\
\text { risk of political change in elections [ ... ] and the change of leadership" C1 } \\
\text { "ISO standards are always seen as a cost of doing business. But it keeps } \\
\text { people safe, protects the environment, and keeps everyone out of jail" C1 } \\
\text { "The implementation of the DWQMS was too onerous [ ... ] for smaller } \\
\text { municipalities [... ]. They will find [an EMS or ISO 14001] really hard to } \\
\text { afford" C2 }\end{array}$ \\
\hline $\begin{array}{c}\text { Provincial Regulatory } \\
\text { Priorities }\end{array}$ & $\begin{array}{l}\text { - } \text { "the new thing is to have sector specific standards; as an example, the ISO } \\
14001 \text { was criticized because it was not deep enough for energy. [So then ISO } \\
\text { came up] with ISO } 50001 \text { for energy" C1 } \\
\text { "the MECP should address EMS as part of the DWQMS, and also should have } \\
\text { a sector-specific EMS for wastewater. Also, they should leave it to the CSA } \\
\text { Group and/or ISO to develop the standard-leave it to the hands of the } \\
\text { experts" C1 } \\
\text { "For wastewater systems, the core structure should be ISO 14001, then add } \\
\text { - } \quad \text { applicable ad-hoc elements of ISO 9001, and the H\&S standards" C1 } \\
\text { "the MECP should not enforce a wastewater management standard. They will } \\
\text { be better off to let it evolve for some more years" C2 } \\
\text { "If MECP decides to support it, then they need to make it flexible enough for } \\
\text { small municipalities [ ... ] and create a repository of SOPs and BMPs, } \\
\text { so municipalities could use them" C2 }\end{array}$ \\
\hline
\end{tabular}

A consistent message from consultants was that if a wastewater management standard was mandated, it should be scalable, flexible and with support mechanisms to allow smaller municipalities to comply with it. Furthermore, there was also a consistent message in that larger municipalities 
are already implementing it or cloning it. Finally, consultants recognized the body of knowledge created by the DWQMS, and the professionalization of the operation, as benefits transferable to the wastewater sector.

Four ENGO representatives participated in the interview process. The participating ENGOs were selected based on having a good governance structure, engaging in relevant activities in Ontario (with water management as a priority) and operating water programs and projects. The four ENGOs were:

- One focused on Ontario rivers and lakes water quality and its users;

- One focused on environmental laws and enforcement;

- One focused on new technologies and innovation in the Ontario municipal water sectors; and

- One focused on North American wetlands and the habitats they provide to wildlife.

The questions posed to the ENGO representatives covered topics A, B and C, and their responses are summarized in Table 4.

Table 4. ENGOs specific viewpoints.

\begin{tabular}{|c|c|}
\hline $\mathbf{Q}$ & ENGOs' Interview Responses Classified under Topics A, B and C \\
\hline $\begin{array}{l}\text { Voluntary Adoption } \\
\text { Non-State MSS }\end{array}$ & $\begin{array}{l}\text { - "Municipalities need to enforce international management systems, } \\
\text { and the province needs to act as a leader. Wastewater is not } \\
\text { regulated and managed in an effective way right now" NG24 } \\
\text { "The voluntary adoption of ISO 14001, or any other EMS for that } \\
\text { matter, could be of assistance for sure, but not a replacement of } \\
\text { regulations" NG23 } \\
\text { "It is hard to regulate/mandate a continual improvement process. } \\
\text { This is more of a cultural change, [for] which typically } \\
\text { management standards are effective" NG23 } \\
\text { "The political question becomes whether a wastewater } \\
\text { management standard should be optional. If it remains optional, } \\
\text { then it takes a back seat" NG23 } \\
\text { "Politically, you need to show [the MSS's] benefits to make it } \\
\text { saleable to elected officials and the public. The ISO certification has } \\
\text { resonance and it should help" NG22 }\end{array}$ \\
\hline Regulatory Barriers & $\begin{array}{l}\text { "If minimum wastewater regulatory requirements were addressed } \\
\text { and identified, then this will lead to intelligent standards, which } \\
\text { will be able to be reviewed over time" NG23 } \\
\text { "A big gap is the enforcement of the law by federal and provincial } \\
\text { governments" NG24 } \\
\text { "[If there was] generic minimum criteria for wastewater [ ... . .] we } \\
\text { can advise on how municipalities are meeting the minimum } \\
\text { requirements" NG23 } \\
\text { "The current regulatory framework [for wastewater] continues to } \\
\text { be a barrier for promoting innovation and new clean water } \\
\text { technologies. The province needs to support risk-based and } \\
\text { holistic approaches. Having an EMS in place will help } \\
\text { municipalities to ensure they are balancing such risks" NG22 } \\
\text { "If the province is promoting risk-based approaches, we need } \\
\text { management tools for checks and balances such as MSS" NG21 } \\
\text { "smaller municipalities are at the mercy of what the province is } \\
\text { going to do for them [ ... ] example: make it scalable, not so } \\
\text { comprehensive for small municipalities [ ... ] it is like a treatment } \\
\text { process: smaller municipalities prefer lagoon systems rather than } \\
\text { mechanical plants" NG21 }\end{array}$ \\
\hline
\end{tabular}


Table 4. Cont.

\begin{tabular}{|c|c|}
\hline $\mathbf{Q}$ & ENGOs' Interview Responses Classified under Topics A, B and C \\
\hline $\begin{array}{c}\text { Provincial Regulatory } \\
\text { Priorities }\end{array}$ & $\begin{array}{l}\text { - } \text { "Civil society cares about environmental outcomes, although they } \\
\text { may not care 'how' [ . . ] Having a sector-specific standard is OK, } \\
\text { but a conversation is needed to understand its value against } \\
\text { competing interests. Making it mandatory without this } \\
\text { conversation might be risky" NG22 } \\
\text { "Smaller municipalities have challenges in dealing with collection } \\
\text { and haulage of septage, its treatment and/or disposal [ . . . ] Small } \\
\text { municipalities need the capital to support haulage to proper } \\
\text { treatment and disposal" NG24 } \\
\text { "The stormwater management fees [ ... ] [are] the correct approach } \\
\text { for municipalities to obtain funding to deal with SWM [ ... ] } \\
\text { [provincial guidelines such as] the sewer bylaw approach can help } \\
\text { smaller municipalities" NG24 } \\
\text { "[The province] has to provide subsidies for green infrastructure, } \\
\text { such as SWM retention practices. This is not as expensive and it is } \\
\text { easy to implement" NG23 } \\
\text { "There should be a more concerted effort by feds, province, and } \\
\text { municipalities to enforce water protection and fisheries } \\
\text { legislation" NG23 } \\
\text { "The province needs to articulate how they can achieve those } \\
\text { [MSS] goals and objectives. Is that the only solution? If the goal is } \\
\text { to reduce sewer system overflows or sewer bypass, then they need } \\
\text { a multi-barrier approach [ ... ] The cumulative effect of such } \\
\text { multi-barrier approach should reduce or eliminate sewers } \\
\text { overflows" NG24 } \\
\text { "There are bi-national [i.e., Canada-USA] implications. [ ... ] If we } \\
\text { are going to manage Lake Erie we need to standardize } \\
\text { management approaches, so we can quantify and document how } \\
\text { we are doing" NG21 } \\
\text { "The province should make the wastewater standard mandatory, } \\
\text { with municipalities to have some latitude to comply with it" NG21 }\end{array}$ \\
\hline
\end{tabular}

In general, all ENGO representatives found common ground in affirming that MSSs are very useful for top management as they provide a sort of peer review through audits, monitoring and other protocols. It was noted that, typically, standards require objectives and processes, and their effectiveness depends on how ambitious those objectives and processes are, among other factors.

One specific aspect noted by one ENGO representative was the gap in financial planning for wastewater and stormwater systems. The ENGO representative noted that during the development of the financial regulation (also known asO. Reg. 453/07), for financial plans of municipal drinking water, to address recommendations by Justice O'Connor [3,4], there were arguments for and against, including wastewater as part of the regulation: $[w]$ e relied on the municipal accounting standard, so we didn't have to re-invent the wheel. The inclusion of wastewater on this regulation had widespread support, sound basis and it had a strong consensus, but in the end the arguments to leave it as a BMP (best management practice) prevailed. So, we ended up with the financial plan requirements only for drinking water, and it was a best management practice for wastewater (NG24). The term BMP means evidence-based guidance to help organizations meet required standards or achieve desired objectives. It differs from MSS in that MSS follows a science-based approach that typically involves a consensus-building process based on a larger, transparent, diverse, collaborative and representative multi-stakeholder approach.

Moreover, as noted by Abouchar et al. (2010: 8), and by the Ontario Sewer and Watermain Construction Association [42], even with O. Reg. 453/07, financial plans for drinking water licensing (containing details on financial position, operations, cash receipts and a consideration of financial 
impacts for a period of at least six years) would not require a full cost recovery model, and as a result, do not provide clear detail on system sustainability, which continues to be a gap for both drinking water and wastewater. Referring to the Walkerton Inquiry [3,4], Abouchar et al. observed the following: [j] ustice $\mathrm{O}^{\prime}$ Connor recognized that full cost accounting and full cost recovery were key components to ensuring the sustainability of water and wastewater systems, and that financial plans should be prepared based on these components [... ]. The Provincial government's role would be to set standards for full cost recovery and to determine the degree to which the government would review and approve these plans [43] (p. 8).

Although there are mandatory requirements for municipal accounting derived from standards and guidelines from the Public Sector Accounting Board (PSAB) of the Canadian Institute of Chartered Accountants, they do not address details of water utilities and their financial sustainability. This is in large part accomplished on a voluntary basis by municipalities in accordance with PSAB guidelines and standards [44].

\section{Discussion: Mind the Gap!}

This section provides a discussion on the regulatory gaps in the water sectors and how those gaps are being addressed to establish the checks and balances for drinking water and for wastewater and stormwater. The analysis is focused on gaps relative to the management of the system. The analysis is performed with the following criteria:

1. The identification of multi-barrier elements for protecting human health developed under the modernized regulatory regime for the drinking water sector. This involves the intertwined approach of three acts, a dozen regulations and guidelines developed after the Walkerton Inquiry (2002) — first column of Table 5.

2. The gaps on the drinking water regulatory framework identified by interview participants as a result of this research-second column of Table 5.

3. The gaps on the municipal wastewater and stormwater regulatory framework in comparison with the recently updated (2004-2008) regulatory framework for the drinking water sector-third and fourth columns of Table 5, respectively.

The legally mandated DWQMS version 2.0 [45] addresses the health hazard risks for drinking water and the specific checks and balances (i.e., critical control points [CCPs] as defined in the Ontario regulations) designed to ensure a systematic approach to accountability, documentation control, updating of operational procedures, internal and external audits, with effective checks and balances according to the plan-do-check-act cycle of the ISO management structure model.

A summary of the regulatory gaps for drinking water, wastewater and stormwater is presented in Table 5. The municipal drinking water gaps include: financial and cost recovery and environmental protection (in the form of regulating the discharge of contaminants to the environment). The cost recovery concept was a recommendation in the Walkerton Inquiry report. While the province required a financial plan (O. Reg. 453/07), the scope of this regulation did not go as far as having full accounting recovery. As noted by Abouchar et al. [43], the difference between O. Reg. 453/07 and full cost recovery is that the regulation "merely requires that the system be financially viable" [43] (p. 8) covering long-term capital investment planning, asset management and approaches for the development of financial plans. Full cost recovery would have required the revenues needed to provide full service, covering source protection costs, operating costs, financing costs, renewal and improvement costs. In this context, having adequate revenue is the key difference. Under the current regulation as it stands now, municipalities are required to financially plan what they can do (with current revenues adjusted annually by inflation), rather than what they should do. In terms of environmental protection as noted in this study, while there was consideration of ISO 14001 when the DWQMS was being developed [7], a review by the author of the original 2006 DWQMS found it did not contain the word "environment" or any clause pointing to "environmental protection." Questioned by the author about this during the 
MWWRC 2017 Annual Conference, an MECP representative very familiar with the DWQMS noted that such environmental protection was left for municipalities to determine as part of Element 21 (continual improvement) of the DWQMS.

Table 5. Comparative analysis: Regulatory gaps and how DWQMS fills them in drinking water.

\begin{tabular}{|c|c|c|c|}
\hline Barrier/Protection & Drinking Water & Wastewater & Stormwater \\
\hline Source water protection & CWA, $\mathrm{NMA}^{1}$ & CWA, NMA & CWA, NMA \\
\hline \multirow{2}{*}{ Financial planning } & \multirow{2}{*}{ O. Reg. 453/07 } & GA P & \multirow{2}{*}{ G A P } \\
\hline & & PSAB Standards & \\
\hline \multirow{2}{*}{$\begin{array}{l}\text { Financial full cost } \\
\text { recovery }\end{array}$} & $\mathrm{GAP}^{2}$ & G A P & G A P \\
\hline & PSAB Standards & PSAB Standards & PSAB Std, SWM fees \\
\hline Effective treatment & $\mathrm{CPP}$ (treatment), SDWA ${ }^{3}$ & Site specific permit & $\begin{array}{c}\text { Site specific permit, } \\
\text { SWM design guidelines }\end{array}$ \\
\hline \multirow{2}{*}{ Minimum design criteria } & \multirow{2}{*}{$\begin{array}{l}\text { SDWA, Design criteria, \& } \\
\text { area-wide permits }\end{array}$} & G A P & G A P \\
\hline & & Design Guidelines & SWM design guidelines \\
\hline \multirow[b]{2}{*}{ Testing \& monitoring } & \multirow{2}{*}{$\begin{array}{c}\text { O. Reg. 248/03, 243/07, } \\
\text { DWQMS }\end{array}$} & G A P (collection) & \multirow[b]{2}{*}{ G A P } \\
\hline & & $\begin{array}{l}\text { Site specific permit } \\
\text { (treatment) }\end{array}$ & \\
\hline \multirow[b]{2}{*}{ Reporting performance } & \multirow[b]{2}{*}{ SDWA, DWQMS } & G A P (collection) & \multirow[b]{2}{*}{ G A P } \\
\hline & & $\begin{array}{l}\text { Site specific permit } \\
\text { (treatment), } \mathrm{PPCP}^{4}\end{array}$ & \\
\hline Operator training & O. Reg 128/04, DWQMS & O.Reg 129/04 & G A P \\
\hline \multirow{2}{*}{$\begin{array}{l}\text { Secured distribution (or) } \\
\text { collection system }\end{array}$} & \multirow{2}{*}{$\begin{array}{l}\text { SDWA, CPP (disinfect) } \\
\text { O. Reg. } 243 / 07\end{array}$} & G A P & G A P \\
\hline & & MTO-OPSD Stds ${ }^{5}$ & SWM design guidelines \\
\hline Emergency response & Permit, DWQMS & Site specific permit & GAP \\
\hline Inspections/audits & DWQMS & GA P & GA P \\
\hline Env. prot'n/discharges & G A P & $\begin{array}{l}\text { OWRA/Site specific } \\
\text { permit }\end{array}$ & $\begin{array}{l}\text { OWRA/Site specific } \\
\text { permit }\end{array}$ \\
\hline
\end{tabular}

\footnotetext{
1. Clean Water Act (O.Reg. 284/07, O.Reg. 288/07), Nutrient Management Act (O. Reg. 267/03, AgriSuite BMP).

2. O. Reg. $453 / 07$ does not include full cost recovery. FCR was a recommendation by Justice O'Connor. 3. Safe

Drinking Water Act (O.Reg. 170/03, O. Reg. 169/03. 4. Ontario Policy F-5-1 for combined sewer systems requires

Pollution Prevention Control Plans (PPCP). 5. Ministry of Transportation (voluntary) ON Provincial Standard

Drawings for sewer systems.
}

As for the regulatory gaps in the wastewater and stormwater sectors, where environmental risks are the main concern, an EMS standard can assist with financial planning, minimum engineering design criteria, performance reporting and inspections/audits. Table 5 identifies those with a red circle; and a white circle those gaps where the MECP is actively working to address through mandatory requirements [46]. One element to consider that constitutes a significant difference with drinking water is the reliance of the wastewater/stormwater systems on design guidelines and BMPs.

Table 5 reveals how the DWQMS is positioned in drinking water governance to address many policy goals identified through the Walkerton Inquiry Recommendations. One example is the reporting requirements. Typically, site-specific approvals require municipalities to report annual performance in treatment, but there are no requirements to report the performance of the collection system (network of sewer pipes and pumping stations). Prioritizing all identified gaps would require a different type of analysis (with an extensive stakeholder consultation process), which is not within the scope of this research.

Prioritizing all identified gaps would require a different type of analysis (more economic and engineering-based with a strong stakeholder consultation process), which is not part of the scope 
of this research. In the context of this study, special attention was directed at gaps associated with the critical control points (CCPs). The CCPs, as pre-identified mitigation factors on drinking water systems, are listed in Table 6, along with their corresponding legislation.

Table 6. Critical Control Points for municipal drinking water systems.

\begin{tabular}{llcc}
\hline \multicolumn{1}{c}{ CCPs-Risk Assessment } & Functionality & \multicolumn{1}{c}{ Specific Regulation } \\
\hline & & Minimum design criteria & O. Reg. 170/03, Permits \\
\cline { 2 - 3 } - $\begin{array}{l}\text { Source water protection } \\
\text { disinfection, treatment plant }\end{array}$ & Certification of operators & O. Reg. 128/04 \\
\cline { 2 - 3 } - $\begin{array}{l}\text { Disinfection-storage } \\
\text { - }\end{array}$ Disinfection-distribution \\
\cline { 2 - 3 } - Water treatment processes & Management framework & O. Reg. 170/03 (DWQMS) \\
\cline { 2 - 3 } - Water storage levels & Financial plans & O. Reg. 453/07 \\
\cline { 2 - 3 } & & Drinking water testing & O. Reg. 248/03 \\
\cline { 2 - 3 } & & Flushing for lead & O. Reg. 169/03 \\
\hline
\end{tabular}

The idea of having CCPs has been identified through the survey-interviews, and the focus group, as necessary to assist in the implementation of costly risk assessments for MSS in wastewater and stormwater systems. Table 7 attempts to draw parallels for wastewater and stormwater systems based on a simplified regulatory functional framework proposed by the author. This table identifies some proposed CCPs for municipal wastewater and stormwater systems.

Table 7. CPPs Proposed for Wastewater/Stormwater Systems.

\begin{tabular}{|c|c|c|}
\hline CCPs-Risk Assessment & Functionality & Specific Regulations \\
\hline \multirow{9}{*}{ 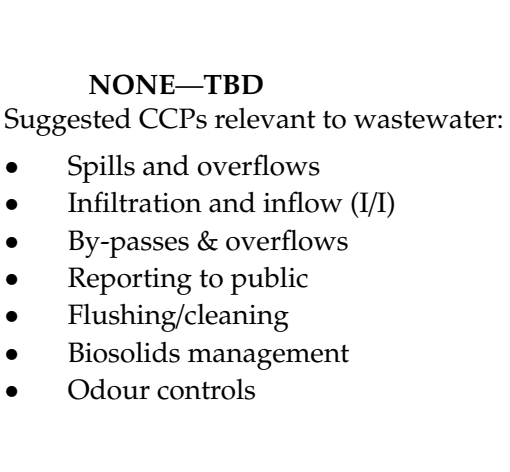 } & Minimum design criteria & None/ISO 14001 \\
\hline & Management framework & None/ISO 14001 \\
\hline & Certification of operators & O. Reg. $129 / 04$ \\
\hline & Wastewater quality standards & Site-specific permit \\
\hline & Wastewater testing & Site-specific permit \\
\hline & Collection system integrity & None/ISO 14001 \\
\hline & Sludge treatment and disposal & $\begin{array}{l}\text { Site-specific permit, } \\
\text { Nutrient Mgmt. Act }\end{array}$ \\
\hline & System performance & None/ISO 14001 \\
\hline & Continual improvement/root causes & None/ISO 14001 \\
\hline
\end{tabular}

Table 7 reveals that while there are some sort of regulatory requirements for the certification of operators, testing and wastewater quality standards, there is nothing on minimum design criteria, EMS (at the provincial level), financial planning, and sewer inspection and cleaning requirements. The proposed CCPs in Table 7 identify the risk factors likely to be addressed in a sector-specific wastewater and stormwater management standard. The risk factors, functionality and "self-regulation" noted under the "specific regulations" column illustrate the risks that could be mitigated by having an ISO 14001, EMS-type of MSS. There are five (5) major gaps where a sector-specific MSS could address:

- generic wastewater municipal design criteria;

- management framework;

- performance reporting;

- $\mathrm{CCP}$ to ensure collection system integrity;

- $\mathrm{CCP}$ to ensure system performance (flushing, cleaning, biosolids management and odour controls).

In summary, the municipal drinking water, wastewater and stormwater sectors in Ontario (and to some extent the rest of Canada) have a clear connection with the sustainable governance model, 
and also with the use of non-state MSSs. Moreover, there appears to be a positive perception among most study participants (state and non-state actors) of the use of MSS standards to govern Ontario's municipal wastewater and stormwater sectors. Lastly, there is evidence that the DWQMS successfully addresses the government's regulatory and environmental objectives $[33,45]$, and there is a perception that some of the regulatory gaps in wastewater and stormwater noted in Table 7 would likely be addressed by an EMS-type standard (see Table 5).

\section{Conclusions}

This study of the use of MSS depicts a form of sustainable governance with the use of MSS, which are initiated, developed and regulated by non-state actors, recognizing the value of non-state rule instruments in the water, wastewater and stormwater sectors. This is evidenced with: (1) the legally required DWQMS, which was developed with elements from the ISO 9001 (QMS), ISO 14001 (EMS) and the HACCP for the food industry; (2) the identification and review of significant gaps in wastewater and stormwater regulation (compared with the drinking water sector); and (3) the use by the three levels of government of environmental MSS, who either through Canadian court decisions, court hearings and referencing in legislation, strongly suggest to incorporate and strengthen the regulatory framework of these sectors with environmental EMS.

Twelve municipalities in Ontario have adopted or are in the process of adopting an ISO 14001 certification for their wastewater and/or stormwater systems, which represents $66 \%$ of Ontario's population. With the large urban centres (e.g., Toronto, York Region, Durham Region, Halton Region) adopting environmental MSS, this is likely to influence small-to-medium-sized cities to follow a similar path. However, small-to-medium-sized municipalities may not have the resources readily available to do this. This study also reveals gaps left unattended in the municipal wastewater and stormwater sectors in comparison with the recently updated (2004-2008) regulatory framework for the drinking water sector. Based on this study: (1) an environmental MSS is perceived as a necessary tool in the Ontario municipal wastewater and stormwater sectors; and (2) further economic cost-benefit analysis or having practical examples with smaller municipalities may be useful to assist a small-to-medium cohort of utilities voluntarily adopting an environmental MSS for their wastewater and stormwater systems.

In addressing the research question: are management system standards likely to have neutral, positive or negative effects on the performance of Ontario municipal water management activity? The qualitative analysis of the interviews revealed that the majority of respondents identified the following objectives in favour of MSS:

- to reduce the likelihood of potential environmental violations;

- to improve compliance and accountability;

- to align with the risk-based approaches of the post-Walkerton drinking water regulations; and

- to complement the regular (and less-frequent) MECP inspections with independent (3rd party) inspections and audits.

In terms of perceptions of MSSs having neutral, positive or negative effects on municipal water systems, $96 \%$ of respondents (24/25) concluded that implementing an EMS would have positive effects for the municipal water sectors.

A total of 304 responses discussed enabling aspects of MSSs for the water sectors and 119 identified barriers to adopting MSSs. This means that nearly three quarters of respondent arguments supported the adoption of MSSs for wastewater and stormwater systems. One of the most popular discussions concerned the need to have a similar risk-based approach for wastewater and stormwater aligned to the existing drinking water regulatory framework. This idea suggests the consistent perception towards a policy convergence occurring in the adoption of MSSs in municipal water sectors.

In addressing the research question: which MSS relevant to the water sectors (ISO 9001-QMS, ISO 14001-EMS and HACCP) are best suited to address municipal water, wastewater and stormwater activity? this study found that there was widespread agreement among respondents that the ISO 9001 
was the correct standard on which to base the DWQMS. While the DWQMS was perceived as the best fit for the drinking water system, securing ISO 9001 certification for drinking water in addition to implementing the DWQMS would be redundant as DWQMS already addresses water quality controls. There was recognition that the new DWQMS version 2.0 (2017) addressed the investigative, continual improvement and audit aspects of the 2007 DWQMS. There was also widespread agreement among respondents that ISO 14001 would work well as a MSS for the wastewater and stormwater sectors.

Of note, $80 \%$ of respondents identified the ISO and the CSA Group (the largest national standard body in Canada) as organizations well suited for the development of quality and environmental MSS for the water sectors. The new DWQMS [45] publication addressed two regulatory gaps identified in the research undertaken for this study: namely, (1) the value of including a continual improvement process; and (2) a documented investigative process for corrective actions (e.g., root cause analysis). However, at the present time, there is no equivalent incorporation of any MSSs with respect to the municipal wastewater and stormwater sectors.

In summary, this study should assist academics, governments and non-state actors in understanding the ways in which non-state MSS can and are being used in support of public policy objectives, and the practical utility of the Ontario provincial government legislatively requiring that Ontario municipalities adopt an EMS standard to assist in meeting Ontario environmental public policy objectives, in a similar manner to the way the provincial government has required Ontario municipalities to adopt a quality management system standard to assist in meeting public policy objectives concerning the provision of safe drinking water sector.

Funding: This research was funded by the Ryerson Graduate Award, the Mitacs Accelerate Program, in partnership with SAI Global; and the Ryerson University's Geoffrey Bruce Fellowship in Fresh Water Policy. This study also received the in-kind contributions of 25 interview participants, who generously provided their time and knowledge to meet with the author and respond and elaborate on the multiple questions given to them.

Conflicts of Interest: The author declares no conflict of interest.

\section{References}

1. Hrudey, S.E.; Hrudey, E.J. Safe Drinking Water: Lessons Learned from Recent Outbreaks in Affluent Nations; IWA Publishing: London, UK, 2002.

2. Wellington, A.; Burley, C.; Rollinson-Lorimer, M. Chapter 14: The Walkerton tragedy: A Comprehensive chronology. In Environmental Law and Policy in the Canadian Context; Captus Press: Concord, ON, Canada, 2010; pp. 511-538.

3. O'Connor, D.R. Part. One of the Report of the Walkerton Inquiry; Queen's Printer for Ontario: Toronto, ON, Canada, 2002.

4. O'Connor, D.R. Part. Two of the Report of the Walkerton Inquiry - A Strategy for Safe Drinking Water; Queen's Printer for Ontario: Toronto, ON, Canada, 2002.

5. Johns, C.M. The Walkerton Inquiry and Policy Change, Commissions of Inquiry and Policy Change; University of Toronto Press: Toronto, ON, Canada, 2014; pp. 214-243.

6. Tovilla, E.; Webb, K. Examining the emerging environmental protection policy convergence in the Ontario municipal drinking water, wastewater and stormwater sectors. Water Qual. Res. J. 2017, 52, 209-228. [CrossRef]

7. City of London, Regional Water Boards Receive Ontario Public Works Association Awards-Staff Report of 28 January 2008. Available online: http://council.london.ca/councilarchives/agendas/environment $\% 20$ and $\%$ 20transportation\%20committee\%20agendas/etc\%20agendas\%202008/2008-01-28\%20agenda/item\%201.pdf (accessed on 12 October 2018).

8. Kollman, K.; Prakash, A. EMS-based environmental regimes as club goods: Examining variations in firm-level adoption of ISO 14001 and EMAS in U.K., U.S. and Germany. Policy Sci. 2002, 35, 43-67. [CrossRef]

9. Fulponi, L. Private voluntary standards in the food system: The perspective of major food retailers in OECD countries. Food Policy 2006, 31, 1-13. [CrossRef] 
10. Tovilla, E. Examining the Evolving Environmental Protection Policy Convergence in the Ontario Municipal Water, Wastewater, and Stormwater Sectors: Analysis of State/Non-State Governance and Value of an Environmental Management System Standard for the Wastewater and Stormwater Sectors. Ph.D. Thesis, Ryerson University, Toronto, ON, Canada, 2020.

11. ISO 14001 Environmental Management System Standard. Available online: https://www.iso.org/standard/ 60857.html (accessed on 31 August 2020).

12. US. EPA. Guide for Evaluating Capacity, Management, Operation, and Maintenance (CMOM) Programs at Sanitary Collection Systems. 2015. Available online: www3.epa.gov/npdes/pubs/cmom_guide_for_ collection_systems.pdf (accessed on 2 January 2017).

13. WEF (not/dated). The O\&M in CMOM: Operation and Maintenance-A Reference Guide for Utility Operators. Water Environment Federation. (O\&M Ver. 2.3a). Available online: www.cmom.net/WEF_ CMOM_O\&M_V23a.doc (accessed on 2 September 2018).

14. WDNR. Green Tier-Biennial Report. Wisconsin Department of Natural Resources. 2014. Available online: http://dnr.wi.gov/files/PDF/pubs/co/CO574.pdf (accessed on 18 November 2015).

15. Rhoads, W.J.; Garner, E.; Ji, P.; Zhu, N.; Parks, J.; Schwake, D.O.; Pruden, A.; Edwards, M.A. Distribution efficiencies operational deficiencies coincide with reported Legionnaire disease clusters in Flint, Michigan. Environ. Sci. Technol. 2017, 51, 11986-11995. [CrossRef] [PubMed]

16. Michigan State. The Michigan Guide to Environmental, Health and Safety Regulations. 2018. Available online: www.michigan.gov/documents/deq/deq-tou-EHSguide-complete_604181_7.pdf (accessed on 21 June 2019).

17. Behm, D. Milwaukee marks 20 years since Cryptosporidium outbreak. W. Journal. 6 April 2013. Available online: www.jsonline.com/news/milwaukee/milwaukee-marks-20-years-since-cryptosporidium-outbreak099dio5-201783191.html (accessed on 9 January 2016).

18. Naumova, E.N.; Egorov, A.I.; Morris, R.D.; Griffiths, J.K. The elderly and waterborne Cryptosporidium infection: Gastroenteritis hospitalizations before and during the 1993 Milwaukee outbreak. Emerg. Infect. Dis. 2003, 9, 418-425. [CrossRef]

19. Webb, K. Sustainable governance in the twenty first century: Moving beyond instrument choice. In Designing Government: From Instruments to Governance; Elias, P., Hill, M., Howlett, M., Eds.; McGill-Queen's Press: Montreal, QC, Canada, 2005; pp. 242-280.

20. Weiss, T.G. Governance, good governance and global governance: Conceptual and actual challenges. Third World Q. 2000, 21, 795-814. [CrossRef]

21. Chatterji, A.K.; Toffel, M.W. How firms respond to being rated. Strateg. Manag. J. 2010, 31, 917-945. [CrossRef]

22. Simpson, D.; Sroufe, R. Stakeholders, reward expectations and firms' use of the ISO14001 management standard. Int. J. Op. Prod. Manag. 2014, 34, 830-852. [CrossRef]

23. Arimura, T.H.; Hibiki, A.; Katayama, H. Is a voluntary approach an effective environmental policy instrument? A case for environmental management systems. J. Environ. Econom. Manag. 2008, 55, 281-295. [CrossRef]

24. Hart, S.L.; Milstein, M.B. Creating sustainable value. Acad. Manag. Exec. 2003, 17, 56-69. [CrossRef]

25. Henriques, I.; Sadorsky, P. Voluntary environmental programs: A Canadian perspective. Policy Stud. J. 2008, 36, 143-166. [CrossRef]

26. Darnall, N.; Potoski, M.; Prakash, A. Sponsorship matters: Assessing business participation in governmentand industry-sponsored voluntary environmental programs. J. Public Adm. Res. Theory 2010, 20, $283-307$. [CrossRef]

27. Delmas, M.A.; Montes-Sancho, M.J. An institutional perspective on the diffusion of international management system standards: The case of the Environmental Management Standard ISO 14001. Bus. Ethics Q. 2011, 21, 103-132. [CrossRef]

28. Delmas, M.A.; Montiel, I. The diffusion of voluntary international management standards: Responsible care, ISO 9000, and ISO 14001 in the chemical industry. Policy Stud. J. 2008, 36, 65-93. [CrossRef]

29. Searcy, C.; Morali, O.; Karapetrovic, S. An analysis of ISO 14001 and suggested improvements. J. Glob. Responsib. 2012, 2, 278-293. [CrossRef]

30. Heras-Saizarbitoria, I.; Boiral, O. ISO 9001 and ISO 14001: Towards a research agenda on management system standards. Int. J. Manag. Rev. 2013, 15, 47-65. [CrossRef]

31. Franceschini, F.; Gelatto, M.; Cecconi, P. A worldwide analysis of ISO 9000 standard diffusion: Considerations and future development. Benchmark. Total Supply Manag. 2006, 13, 523-541. [CrossRef] 
32. Tovilla, E. Value of a made-in Ontario management system standard for municipal wastewater and stormwater activities. Water Qual. Res. J. under review.

33. CELA. Ontario Safe Drinking Water Act, 2002 \& its regulations: Canadian Environmental Law Association. 25 November 2011. Available online: www.cela.ca/sites/cela.ca/files/Water-FAQs-Eng.pdf (accessed on 12 January 2019).

34. Lin, P.; Yuan, X.; Tovilla, E. Integrative modeling of performance deterioration and maintenance effectiveness for infrastructure assets with missing condition data. Cumput. Civ. Infrastruct. Eng. 2019, 34, 677-695. [CrossRef]

35. Tovilla, E.; Lin, P.; Yuan, A. Region of Peel Wastewater Collection System: Evidence-Based, Risk-Informed Asset Management Strategy. Canadian Water and Wastewater Association. Available online: https: //www.nxtbook.com/naylor/CWWB/CWWB0218/index.php?startid=6\#/p/10 (accessed on 2 January 2019).

36. Cresswell, J.W.; Plano Clark, V.L.; Gutmann, M.L.; Hanson, W.E. An Expanded Typology for Classifying Mixed Methods Research into Designs, Chapter 7-Advanced Mixed Methods Research Designs; Sage Publications: Thousand Oaks, CA, USA, 2007.

37. Carter, N.; Bryant-Lukosius, D.; DiCenso, A.; Blythe, J.; Neville, A.J. The use of triangulation in qualitative research. Oncol. Nurs. Forum 2014, 41, 545-547. [CrossRef]

38. Wong, K.C. Using an Ishikawa diagram as a tool to assist memory and retrieval of relevant medical cases from the medical literature. J. Med. Case Rep. 2011, 5, 120. [CrossRef] [PubMed]

39. Stamatis, D.H. Failure Mode and Effect Analysis, 2nd ed.; ASQ Quality Press: Milwaukee, WI, USA, 2003.

40. Strong, R. CAPA and Root Cause Analysis for the Food Industry. Available online: https://foodsafetytech. com/feature_article/capa-and-root-cause-analysis-for-the-food-industry/ (accessed on 12 October 2018).

41. Yin, R.K. Case Study Research: Design and Methods, 3rd ed.; SAGE Publications: Thousand Oaks, CA, USA, 2003.

42. OSWCA. Creating Water Infrastructure Sustainability through a Provincial Rate Setting Authority-White paper, Ontario Sewer and Watermain Construction Association. 2016. Available online: www.oswca.org/uploads/may-2016-white-paper-creating-water-infrastructure-sustainabilitythrough-a-provincial-rate-setting-authority.pdf (accessed on 12 January 2019).

43. Abouchar, J.; Vince, J. Ten years after Walkerton-Ontario's drinking water protection framework update. Report No. 403101. Available online: http://www.cba.org/cba/cle/PDF/ENV11_Abouchar_paper.pdf (accessed on 12 October 2016).

44. MMA-Ministry of Municipal Affairs. Common Language Guide to Municipal Financial Statements. Available online: www.mah.gov.on.ca/AssetFactory.aspx?did=15792 (accessed on 12 January 2019).

45. MECP. Drinking Water Quality Management Standard-Version 2.0. 2017. Available online: www. downloads.ene.gov.on.ca/envision/env_reg/er/documents/2017/012-5530_FinalStandard.pdf (accessed on 12 January 2019).

46. WEAO. MECP Wastewater Design Criteria and Holistic Approach for Collection and Stormwater Approvals. WEAO Government Affairs Committee, Influents Spring 2019, 71. Available online: https://www.weao.org/ influents (accessed on 10 May 2019).

(C) 2020 by the author. Licensee MDPI, Basel, Switzerland. This article is an open access article distributed under the terms and conditions of the Creative Commons Attribution (CC BY) license (http://creativecommons.org/licenses/by/4.0/). 